\title{
Understanding Language Teaching From Method to Postmethod B. Kumaravadivelu,
}

\author{
(ESL \& Applied Linguistics Professional Series) \\ Taylor \& Francis e-Library, 2008.
}

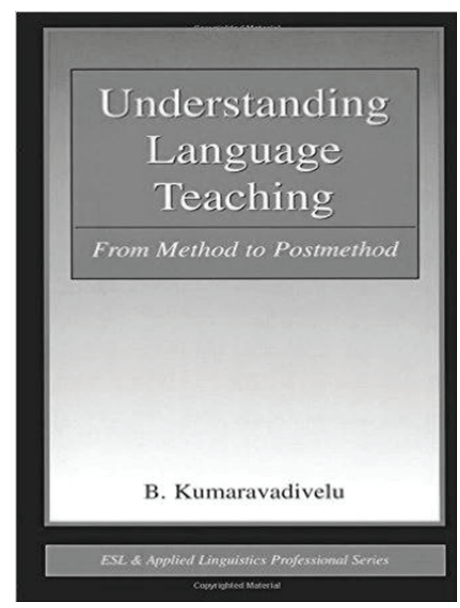

\section{Reviewed by Nancy Bautista Perez ${ }^{2 *}$ Universidad del Tolima}

Professor B. Kumaravadivelu presents his second widelyacclaimed book, Understanding Language Teaching, about the macrostrategy framework designed to empower both beginning and experienced language teachers to develop their own theory of practice which gives them autonomy. This book is a response to the many challenges teachers have to face in their English classroom, but at the same time is a calling out for a coherent and comprehensive framework for teacher preparation in these times of globalization,

\footnotetext{
1 Received: November 30, 2016/Accepted: April 26, 2017

2 nybautistap@ut.edu.co
} 
rapidly accelerating social, technology, cultural and economic changes and trends that implies that new studies advocate the construction of pedagogies of world Englishes and English as a lingua franca as suggested by Jenkins (2006) are needed; and the postmethod framework is a great opportunity to start this process.

This macrostrategy framework is considered by many scholars and practitioners as the answer to years of limitations of the traditional methods or as defined by Kumaravadivelu "The Postmethod Pedagogy is an alternative to method rather than a method, while alternative methods are primarily products of top-down processes, alternatives to method are mainly products of bottom-up processes" (Kumaravadivelu, 2003, p.33); this postmethod framework is considered the most comprehensive because it includes key concepts and combines elements of the field of English Language Teaching (ELT) of both Allwrigth's and Stern's frameworks previously to Kumaravadivelu's thoughts, which is founded on three parameters based on social, cultural, economic and politic dimensions that have permeated the process of language teaching, at the same time those parameters are complemented by ten macrostrategies or classroom principles. (Kumaravadivelu, 2003).

Although, this gripping book was published in 2008, the postmethod pedagogy is considered a sustainable approach to language teaching in Latin America because it is sensitive to local particularities and involves a critical awareness of local conditions and needs. Therefore, in countries such as Brazil and Argentina researchers and language teachers have carried out projects to analyze and develop their own pedagogies inspired and based on this framework; an example of it can be found in one of the Mercer's articles published in 2013 in Brazil. Also, in the 39th FAAPI conference in Argentina in 2014, researchers and scholars emphasized on the benefits for the bilingual education that this pedagogy offers. However, in Colombia little implementation and studies have been conducted and most of them are about teaching culture, influenced by the post-method thoughts as Fandiño, (2014) shows his concern about the incorporation of culture into the teaching of English as a foreign language within the context of Colombia Bilingüe, in his article, Teaching culture in Colombia Bilingüe: From theory to practice. Thus, the author has called this book "the pattern which connects" all the elements to what language teachers are expected to do in the classroom nowadays (Kumaravadivelu, 2008. P. xiii); it means that the teacher should be a mediator and generator of learning opportunities by connecting the classroom with the local and global community, as stated by Byram and Risager (1999) teachers act as mediators between cultures. 
The text is divided into three main parts and each part is split up into chapters and most of the chapters are characterized by presenting a review of theories regarding the fundamental features of language, language learning and teaching along with critical reflection and examples from real classroom practices.

Part One: Language, Learning, and Teaching. Addresses general features and contributions that applied linguistics has done to L2 is highlighted by the author. It is divided into three chapters: Chapter 1: Language, Concepts and Precepts explores the fundamental concepts of language and introduces three different pedagogical concepts: Language as a system, as discourse and as ideology and discusses the principles of each one from different researchers and scholars. Chapter 2: Learning: Factors and Processes analyzes the concepts of intake, intake factors, and intake process to understand the factors and processes that will contribute to successful learning or non-learning of L2 (Second Language Acquisition) and how the language teacher should construct a pedagogy to promote language learning in the classroom. Chapter 3: Teaching: Input and Interaction. This chapter focuses on some aspects of input, interaction, and syllabus design that impact classroom instruction and consequently the language acquisition.

Part two: Language Teaching Methods. It is divided into three chapters; four, five and six. The author takes a critical look at some established and well-known language teaching methods and connects them to the fundamental features addressed in Part One; then concludes with the theoretical principles and classroom procedures of languagelearner-, and learning-centered methods. Chapter four: Constituents and Categories of Methods, which explains and provides rationale behind the categorization of language methods presented in the book. It distinguishes between Method and Methodology: Approach, Method and Technique, Approach, Design and Procedure, Principles and Procedures. It also classifies the language teaching methods: LanguageCentered Methods, Learner-Centered Methods, Learning-Centered Methods, and summarizes them into a figure and introduces the Taskbased Language Teaching (TBLT). Chapter five: Language-Centered Methods clarifies how language teaching methods have evolved and improved over time due to dissatisfaction, therefore a new one emerged. Also, it discusses some historical, psychological, and linguistic factors that shaped the language-centered pedagogy for almost 25 years. In addition, it reviews some theoretical principles and the classroom procedures, and how the dissatisfaction with the language centered pedagogy motivated the search for a better method resulting on the advent of the communicative language teaching as an example of the learner-centered pedagogy. Chapter six: Learner-Centered Methods 
explains how this pedagogy has influenced in the classroom procedures that emphasizes in the communicative language teaching from its earlier and later versions. However, some experts like (Nunan,1987 and Thornbury, 1996), revealed without any doubt that the so-called communicative classrooms are anything but communicative. Nunan concluded that in one of the classes he observed "there is growing evidence that, in communicative class, interactions may, in fact, not be very communicative after all" (Nunan, 1987,p.144). Chapter seven: Learning-Centered Methods or Pedagogy defines and describes the theoretical principles and classroom procedures regarding to the Natural Approach and Communicational Teaching Project that represents the learning-centered pedagogy and how to develop appropriate interactional activities, for example Krashen himself laments that the "only weakness" of the NA "is that it remains a classroom method, and for some students this prohibits the communication of interesting and relevant topics" (Krashen, 1982, p. 140). This chapter discusses and concludes about the limitations of the concept of method and highlights some of the attempts to transcend those limitations.

Part Three: Postmethod Perspectives. It is the last part of the book and it shows, in three chapters, the new challenges and opportunities that the new millennium has brought to the learning and teaching pedagogies and classroom procedures. Scholars such as Allwright (1991), Pennycook (1989), Prabhu (1990), and Stern (1992) have not only cautioned language-teaching practitioners against the uncritical acceptance of untested methods but they have also counseled them against the very concept of method itself. Also, it analyzes how methods go through endless cycles of life, death, and rebirth. And presents what the author has called the postmethod condition as an alternative to the new challenges to ELT, English Language Teaching field. Chapter eight: Postmethod Condition shows the limits of method as, the meaning of method and the death of method. Most of the definitions about method coincided that is something planned and implies an order. In addition, it analyzes five myths about methods according to what research has disclosed. For example, Kumaravadivelu, (1993), Nunan, (1987); Swaffer, Arens, \& Morgan, (1982) have revealed four interrelated facts that Kumaravadivelu (2008, p. 166) summarizes like this "In other words, teachers seem to be convinced that no single theory of learning and no single method of teaching will help them confront the challenges of everyday teaching. They use their own intuitive ability and experiential knowledge to decide what works and what does not work". To sum up, this chapter attempts to deconstruct the existing concept of method, the antimethod sentiments and delineates the emerging postmethod condition. Chapter nine: 
Postmethod Pedagogy discloses the foundation for the construction of pedagogies that can be considered postmethod in their orientation. The author considers that the proposals that have the requirements are only three: 1.Stern's Three-dimensional framework, Allwright's Exploratory Practice framework and his own, Kumaravadivelu's macro-strategic framework. In this chapter he analyzes and exemplifies each of them. Furthermore, this chapter introduces the pedagogic wheel which has an axle represented by the three parameters; particularity, practicality, and possibility interconnected with the ten macrostrategies. Finally, the aim of this framework is to empower teachers to construct their own macrostrategies and microstrategies (tasks) according to local context needs. It clarifies that this is the first step and this framework is still evolving. Chapter ten: Postmethod Predicament considers the challenges and changes teachers should face when trying to implement the postmethod pedagogy. There are two main barriers the pedagogical and the ideological. It concludes by arguing that the transitional path from the long established methods-based pedagogy is, no doubt, paved with challenging barriers.

The way this book was written "based on theoretical, experimental and experiential knowledge, teachers and teacher educators have expressed their dissatisfaction with method in different ways". Kumaravadivelu (1993b), offers a unique opportunity to language teachers to reflect upon their teaching practice through the analysis of different experts' opinions, microstrategies and examples taken from real classrooms. It captivates and helps readers to be aware of what pedagogical practices are required today and what teachers who are concerned with the ethical, sociocultural, historical, and political issues that impact the students' lives are expected to do to prepare them as local and global citizens.

To sum up, this book is a great contribution to the ELT field since it empowers institutions, language teachers and students to be more aware of the importance of teaching and learning English and the status it has as an international language. "A language achieves a genuinely global status," observes David Crystal (2003, p. 3), the author of English as a Global Language, "when it develops a special role that is recognized in every country." And finally, the role of the 21 st century education which is to establish links with society and prepare students for the demands of the social necessities and working world by developing competences that students need to use in the workplace and society; these competences are clearly exposed in each macrostrategy of the postmethod framework that recognizes that the nature of any language pedagogy should be socially-realistic and contextually-sensitive. 


\section{References}

Allwright, R. L. (1991). The death of the method (Working Paper \#10). The Exploratory Practice Centre, The University of Lancaster, England.

Byram, M. and Risager K. (1999). Language Teachers Politics and Cultures, Multilingual Matters Ltd., Philadelphia, USA.

Crystal, D. (2003). English as a Global Language, Second Edition, Cambridge University Press, United Kingdon.

Jenkis, H. (2006). Where Convergence Culture: Where Old and New Media Collide, University Press, New York

Krashen, S. (1982). Principles and practice in second language acquisition. New York: Pergamon Press.

Kumaravadivelu, (2003) Beyond Methods: Macrostrategies for Language Teaching. Yale University Press New Haven London. Published with assistance from the Louis Stern Memorial Fund. Copyright $(\mathcal{C} 2003$ by Yale University.

Kumaravadivelu, B. (1994a). The postmethod condition: (E)merging strategies for second/foreign language teaching. TESOL Quarterly, 28:1:27-48.

Kumaravadivelu, B. (1993b). The name of the task and the task of naming: Methodological aspects of task-based pedagogy. In G. Crookes \& S. Gass (Eds.), Tasks in a pedagogical context (pp. 6996). Clevedon, England: Multilingual Matters.

Nunan, D. (1987). Communicative language teaching: Making it work. ELT Journal 41/2:136-45

Pennycook, A. (1989). The concept of method, interested knowledge, and the politics of language teaching. TESOL Quarterly, 23, 589618.

Prabhu, N. S. (1990). There is no best method - why? TESOL Quarterly, 24, 161-176.

Stern, H. H. (1992). Issues and options in language teaching. Oxford: Oxford University Press.

Swaffar, J., Arens, K., \& Morgan, M. (1982). Teacher classroom practices: Redefining method as task hierarchy. Modern Language Journal, 66, 24-33. 
Thornbury, S. (1996). Teachers research teacher talk. ELT Journal, 50: $279-88$.

A.P.I.S.E. Asociación de Profesores de Inglés de Santiago del Estereo. FAAPI Conference 39th. English Language Teaching in the postmethod era: A view from Argentina. ISBN 978-987-24550-1-9. , Santiago del Estereo, Argentina, 2014.

Colombian Applied Linguistics Journal, 16(1). 81-92.Teaching Culture in Colombia Bilingüe: From Theory to practice. Printed ISN 01234641 (pages: 81-92), Vol.16., January-June 2014. http://dx.doi. org/10.14483/udistrital.jour.calj.2014.1.a07

RBLA, Revista Brasileira de Linguística Aplicada, ISSN: 1676-0786, Belo Horizonte, V.13,n.2,p.375-398. 2013.rblasecretaria@gmail. com, Universidade Federal de Minas Gerais. The text is available at:https://flteducation.wikispaces.com/file/view/kumaraPosmethod. pdf

This book review has not been previously published, and is not being considered for publication elsewhere.

Author

*Nancy Bautista Pérez has a B.A. in English, a Specialization in English Teaching and is working on a research project for an M.A. in English Didactics at Tolima University. She has twelve years of experience as a language teacher in both English and Portuguese. She has worked for Universidad de Ibagué, and Universidad del Tolima, Currently, she is a full time professor at the Universidad Cooperativa. In 2009 she participated in a "Diplomado in lingua portuguesa" in Leticia Amazonas, and in 2015 she was one of the speakers in the 3rd.Conference of Foreign Language Research at the Tolima University the topic was about the importance of Understanding and Reflecting upon Language Policies. 